\title{
Certiorari and the Local Board
}

\author{
Shelden D. Elliott*
}

T Has long been established by decisions of the Califorma Supreme Court that the writ of certiorari lies in proper cases to review determinations made by local administrative boards and officers. This contrasts with the recent holding that the same writ cannot be used to obtain judicial review of the determinations of state-wide administrative agencies. ${ }^{1}$ Dicta in recent opinions indicate that the court does not intend its new rule with respect to state-wide agencies to affect its old rule as to local agencies, ${ }^{2}$ but the opinions offer little or nothing to rationalize the distinction. They merely make two contrasting assertions: (1) Boards and officers having state-wide jurisdiction cannot, without explicit constitutional sanction, be given judicial functions; therefore their proceedings cannot be reviewed on certiorari. (2) Local boards and officers can be vested with judicial power and the writ of certiorari is available to review and, if need be, to annul their judicial acts.

Why this differentiation between the local and the state-wide board? Certain cases are referred to by the court as "not in point" as to state-wide agencies because such cases "involved the scope or validity of judicial powers exercised by local tribunals, boards, or officers whose jurisdiction was limited to incorporated cities, towns, townships, counties, or cities and counties ...."3 Is the judicial power something to be parcelled out by the legislature in geographical segments? Must a judicial function, if it is to be exercised by an administrative officer, be fenced in by a city or a county boundary line?

Occasional references by the court to article VI, section 1 , of the state constitution ${ }^{4}$ are not particularly helpful in supplying the an-

*Professor of Law, University of Southern California; A.B., Yale University; J.D., LL.M., University of Southern California. Author of articles in legal periodicals.

I Standard Oil Co. v. State Board of Equalization (1936) 6 Cal. (2d) 557, 59 P. (2d) 119.

2 Ibid. at 560,59 P. (2d) at 120, quoting frown Department of Public Works v. Superior Court (1925) 197 Cal. 215, 239 Pac. 1070. See also Drummey v. State Bd. of Funeral Directors (1939) 13 Cal. (2d) 75, 81, 87 P. (2d) 848, 852.

3 Standard Oil Co. v. State Board of Equalization, supra note 1, at 561, 59 P. (2d) at 120, quoting from Department of Public Works v. Superior Court, supra note 2, at 221, 239 Pac. at 1079.

${ }^{4}$ CaI. Const. art. VI, $\S 1$ : "The judicial power of the state shall be vested in the senate, sitting as a court of impeachnent, in a supreme court, district courts of appeal, 
swer. " Except for local purposes'", we are told, "section 1 of article VI of the Constitution confines all judicial power to certain specified courts." And again, in Drummey v. State Board of Funeral Directors" the court remarks that that section "vests the entire judicial power of the state in the courts, except as to local boards, and the railroad and industrial accident commissions, which are governed by special constitutional provisions". Do these statements imply that for certain purposes local boards are actually "inferior courts" established by the legislature as proper repositories of judicial power pursuant to said article and section ${ }^{7}$ Or does the propriety of giving them judicial functions stem, either expressly or by necessary implication, from provisions found elsewhere in the constitution? ${ }^{8}$

To the extent that certiorari is now recognized as a proper mode for reviewing local determinations the above questions are perhaps largely academic. Yet they also introduce further problems of current interest. What types of acts or functions are "judicial", so that the writ will lie? Where it does lie, what is the extent of the review obtainable?

These are all questions to which the court has not yet given us the final answers. However, a brief review of the more significant cases in California from the early days down to the present time may help in understanding both the origin and the development of the special doctrines applicable to judicial review of local boards. The materials that follow represent a rather pedestrian effort to trace briefly this historical development.

superior courts, such mumicipal courts as may be established in any city or county, and such inferior courts as the legislature may establish in any incorporated city or town, township, county or city and county."

5. Standard Oil Co. v. State Board of Equalization, supra note 1, at 560, 59 P. (2d) at 120. (Italics added.) Dicta to the same effect are found in Pacific Coast Casualty Co. v. Pillsbury (1915) 171 Cal. 319, 322, 153 Pac. 24, 26; Western Metal Supply Co. v. Pillsbury (1916) 172 Cal. 407, 413, 156 Pac. 491, 494.

${ }^{6}$ Supra note 2, at 81,87 P. (2d) at 852 .

7 This interpretation has been advanced by Mr. Rode, who suggests the theory that such local agencies "are courts of local jurisdiction which the legislature is authorized to establish under article VI of the Constitution". Note (1937) 25 CaLIF. L. Rev. 694, 704.

It is also indicated in the recent critical analyses by Professors McGovney and Turrentine. McGovney, Administrative Decisions and Court Review Thereof, in California (1941) 29 Calr. L. Rev. 110, 145-146; Turrentine, Restore Certiorari to Review StateWide Administrative Bodies in California, ibid. at 275, 277, $\mathrm{n}$.

8 In the quoted excerpt from the Drummey case, text to note 6 , supra, the clause, "which are governed by special constitutional provisions", might be construed as referring also to "local boards". As so construed, it would support the second suggested interpretation, which has also been adopted by early cases and by certain recent decisions, discussed infra. 
Before attempting any survey or classification of the cases, we should have in mind the constitutional and statutory background of the early decisions. Here we find considerable similarity between the original and the present provisions governing judicial power, the establishment of local governing boards, and the writ of certiorari. Article VI, section 1, of the constitution of 1849 , not unlike the present constitution, authorized the legislature to "establish such municipal and other inferior courts as may be deemed necessary". ${ }^{\circ}$ Section 4 of the same article defined the jurisdiction of the supreme court, and the powers of the justices thereof as well as of district and county judges. While it did not expressly refer by name to any of the prerogative writs other than habeas corpus, the section did confer "power to issue all other writs and process necessary to the exercise of their appellate jurisdiction". ${ }^{10}$ In article XI of the constitution, section 4 directed the legislature to "establish a system of county and town governments, which shall be as nearly uniform as practicable throughout the state", and section 5 gave the legislature "the power to provide for the election of a board of supervisors in each county", the supervisors to perform "such duties as may be prescribed by law".

The writ of certiorari was authorized and defined in the Practice Act of $1851,{ }^{11}$ in language substantially the same as that appearing later in the Code of Civil Procedure. The writ of review, the original provision reads, "shall be granted in all cases when an inferior tribunal, board, or officer, exercising judicial functions, has exceeded the jurisdiction of such tribunal, board, or officer; and there is no appeal, nor, in the judgment of the Court, any plain, speedy, and adequate remedy". ${ }^{12}$ The review should extend no further than to determine

9 The section was recast in 1862 to read: "The judicial power of this state shall he vested in a supreme court, in district courts, in county courts, in prohate courts, and in justices of the peace, and in such recorder's and other inferior courts as the legislature may establish in any incorporated city or town." TreadwedL, California Constitution -Annotated (6th ed. 1931) 936. (Italics added.) Clearly, the framers of this amendment did not contemplate county hoards of supervisors or other county officers as heing "inferior courts".

10 It was not until the 1862 amendments that express mention of "certiorari" appeared in article VI, and then only in connection with the supreme court, which was given power to issue writs of mandamus, certiorari, prohibition, and habeas corpus, and also all other writs necessary or proper to the complete exercise of its appellate jurisdiction (section 4). Neither the district courts (section 6) nor the county courts (section 8) were specifically empowered to issue any of the writs other than habeas corpus. TREADWELL, op. cit. supra note 9, at 936-937.

11 Cal. Stats. 1851, p. 123.

12 Ibid. §456; cf. Car. Code Crv. Proc. § 1068. 
whether the inferior tribunal, board, or officer has regularly pursued its authority. ${ }^{13}$

Insofar as the organic law and the statutes are concerned, the availability of certiorari to review administrative decisions should be the same today as it was at the outset. In the case of local boards and officers at least, this seems to have been the course of development, once the basic principles had been definitely established.

Of the local administrative determinations in which the writ of certiorari was first called into operation as a method of review, some of the earliest involved the issuing of licenses to establish public ferries. These early enterprises- "odious monopolies", the court branded them ${ }^{14}$ - were brought under regulatory control by an act of 1850 , vesting discretionary powers in the local courts of sessions as to the granting of licenses. ${ }^{1 \overline{5}}$ In the initial cases wherein review of such grants was sought, the supreme court manifested no particular misgivings as to the propriety of certiorari as the remedy to test excess of jurisdiction in such proceedings. ${ }^{16}$ Later, after the ferry-licensing function had been transferred to county boards of supervisors, we find the court broadly stating: "There can be no doubt of the power of the District Courts to grant a writ of certiorari to review the action of a Board of Supervisors in granting a ferry license."17

As to the availability of certiorari to review other local proceedings, the court was somewhat less certain. There is a rather curious parallel, in spite of the difference in application, between the views expressed in People v. Hester ${ }^{18}$ and those in the recent case of Standard Oil Co. v. State Board of Equalization ${ }^{19}$ and the Drummey case. Certiorari had been sought in the district court to review the action of the board of supervisors of Alameda County in levying a tax for a building or court-house fund. Chief Justice Murray, adverting to the statutory language by which certiorari was confined to inferior courts and bodies "exercising judicial functions", pointed out that since the

13 Cal. Stats. 1851, p. 124, \$462 ; cf. CAL. Code Crv. Proc. $\$ 1074$. Like the certiorari provisions, the original sections relating to mandanus were fundamentally the same as at present. Cal. Stats. 1851, pp. 124-126, §§ 466-479; cf. Car. Code Crv. Proc. §§ 1084 1097.

14 In re Hanson (1852) 2 Cal. 262, 263.

15 Cal. Stats. 1850 , c. 35 , p. 97.

16 See In re Hanson, supra note 14; Wilson v. Board of Super's of Sacramento County (1853) 3 Cal. 386; Chard v. Harrison (1857) 7 Cal. 113.

17 Murray v. Board of Super's of Mariposa County (1863) 23 Cal. 492, 495.

18 (1856) 6 Cal. 679.

19 Supra note 1. 
supervisors were not judicial officers, nor charged with the exercise of judicial functions, the writ could not properly be directed to them. In appropriate cases, he suggested, judicial supervision could be effected "by mandamus, prohibition or injunction; but their proceedings cannot be reviewed by certiorari". ${ }^{20}$

A year later, in People v. Supervisors of El Dorado County, ${ }^{21}$ the Chief Justice frankly admitted the error of his earlier view. The decision in People v. Hester, he explained, was erroneously based on the "separation of powers" clause in article III of the constitution; and a further error lay in overlooking article XI, section 5, giving the legislature power to provide for a board of supervisors for each county, to perform "such duties as may be prescribed by law". Such duties, of necessity, would include judicial as well as legislative and executive functions. ${ }^{22}$ The decision, quite significantly, makes no reference to article VI nor does it attempt to justify a delegation of judicial power to boards of supervisors as "inferior courts". Rather, their judicial functions came ex necessitate from article XI, relating to local government. ${ }^{23}$

There followed a succession of cases in which certiorari seems to have been readily granted to review local determinations insofar as they involved judicial functions and presented reviewable questions. Thus, action of a board of supervisors in determining the insufficiency of an official bond, and declaring the office vacant for failure of the officer to file a new one, was judicial in character. ${ }^{24}$ The Board of Delegates of the San Francisco Fire Department, a voluntary organization confirmed and recognized by statute and municipal ordinance, was held to have acted judicially im deciding a contested election for

20 People v. Hester, supra note 18 , at 681 . Cf., however, Whitten v. California State Board of Optonetry (1937) 8 Cal. (2d) 444, 65 P. (2d) 1296, holding that prohihition is subject to the same hmitations as certiorari in relation to administrative proceedings.

21 (1857) 8 Cal. 58.

22 The Chief Justice also notes his earlier error in placing prohibition on a different basis from certiorari. Ibid. at 62 .

23 Equally interesting is a still later view of the court, suggesting that People v. Supervisors of El Dorado County, supra note 21, was erroneous insofar as the earlier case implied that boards of supervisors were exempted from the "separation of powers" clause only by force of article XI, section 5. "While we agree to what was said as to the meaning of the latter section, we dissent froin the doctrine that in the absence of that section the Legislature could not, by reason of the Third Article, confer mixed functions upon Boards of Supervisors." People v. Provines (1868) 34 Cal. 520, 531.

24 People v. Supervisors of Marin County (1858) $10 \mathrm{Cal}$. 344. See also Miller v. Board of Super's of Sacramento County (1864) 25 Cal. 93, 97: "In the matter of the approval or disapproval of the bond, the Board exercises judicial functions." 
chief engineer of the Department. ${ }^{25}$ Action of a board of supervisors in examining, settling and allowing claims for compensation against the county was an exercise of "judicial or quasi-judicial" power, and could be reviewed on certiorari as to questions of jurisdiction. ${ }^{26} \mathrm{In}$ deed, in one case the court even went as far as to hold that enactment of an ordinance raising salaries was "equivalent to an auditing and allowing of a claim to this extent on the treasury, and involves the same exercise of judicial power ...." ${ }^{27}$ And proceedings of a board of supervisors in establishing a public road were viewed as an exercise of judicial functions as far as review on certiorari was concerned. ${ }^{28}$

The foregoing brief résumé serves to show that the propriety of certiorari to review certain determinations of local boards was well established by the time of the adoption of the Code of Civil Procedure with its re-enactment of the earlier certiorari provisions. Several of the early decisions appear in the annotations to the original code sections. ${ }^{29}$ In general, the numerous cases from 1872 to the decision of the Standard Oil case in 1936 tend merely to confirm the earlier principles, and possibly to clarify the distinction between judicial and other functions of local boards. An exhaustive analysis of all of the cases would serve no useful purpose. It might be helpful, however, to review in outline the broad distinctions laid down, and then to consider a few of the specific types of local action to which the tests have been applied.

General criteria have from time to time been suggested by the California courts for determining that a particular action of a local board or officer is judicial. The earliest decisions preferred to base the test on whether or not the proceeding involved a determination of the "property or rights" of the citizen. ${ }^{30}$ If so, it was judicial and could be reviewed on certiorari. Later, it was recognized that such a test was nuch too broad, and that local action affecting property or other rights might easily be legislative or executive, and not review-

25 Whitney v. Board of Delegates of S. F. Fire Dept. (1860) 14 Cal. 479.

20 El Dorado County v. Elstner (1861) I8 Cal. 144. See also People v. Supervisors of El Dorado County, supra note 21.

27 Robinson v. Board of Super's of the City and County of Sacramento (1860) 16 Cal. 208, 211. Cf., however, Spring Valley Water Works v. Bryant (1877) 52 Cal. 132, in which the court drew a careful distinction between legislative and judicial functions of local boards.

28 Keys v. Board of Super's of Marin County (1871) 42 Cal. 252.

292 Caz. Code Crv. Proc., Annotated (1872) 4-7.

30 Robinson v. Board of Super's of the City and County of Sacramento, supra note 27. See also People v. Supervisors of Marin County, supra note 24. 
able. ${ }^{31}$ Assertion of the well-worn distinction between a legislative and a judicial act has appeared in the usual formula:

"The former establishes a rule regulating and governing matters or transactions occurring after its passage. The other determines rights or obligations of any kind, whether in regard of persons or property concerning matters or transactions which already exist and have transpired ere the judicial power is invoked to pass on them." 32

Thus, a resolution of intention to extend Market Street in San Francisco was a legislative act, whereas a subsequent order declaring it to be a public street and that "said street . . . is hereby condemned, appropriated, acquired, set apart and taken for public use . . . ." was clearly judicial and subject to review on certiorari. ${ }^{33}$ Just as clearly, too, the initial determinative test as to whether the writ would issue lay not in the nature of the tribunal or officer by which the decision was made, but in the "character of the act or determination sought to be reviewed". 34

A really definitive enunciation of principles to guide the courts in ascertaining when a local board acts judicially was first given in $I m$ perial Water Co. v. Board of Supervisors, ${ }^{35}$ where the supreme court laid down a combined substantive and procedural test. Thus, if the action affected an individual's property or rights and was to be taken after notice and hearing, involving the receiving of evidence and other comparable aspects of a proceeding in a court of law, then such action was judicial and reviewable on certiorari. ${ }^{30}$

31 Spring Valley Water Works v. Bryant, supra note 27, at 136: "If it be assumed that an act is judicial because the effect of it may be to deprive a citizen of his property or other right, there is no hmit to the cases in which the writ may be resorted to; and the definition given by the Code, so far as it confines its issuance to tribunals, boards, or officers exercising 'judicial functions,' has no meaning."

32 Smith v. Strother (1885) 68 Cal. 194, 196, 8 Pac. 852, 853.

33 Wulzen v. Board of Super's of the City and County of San Francisco (1894) 101 Cal. 15, 17, 35 Pac. 353.

34 Quinchard v. Board of Trustees (1896) 113 Cal. 664, 668, 45 Pac. 856, 857.

35 (1912) 162 Cal. 14, 120 Pac. 780.

$36 \mathrm{Ibid}$. at 18, $120 \mathrm{Pac}$. at 782. The court went on to apply the test to the proceeding there under review, namely, the organization of an irrigation district by the board of supervisors: "This scheme presents all the usual elements of a judicial proceeding, the notice, the hearing, the taking of evidence, and the judgment. The privilege of using a portion of the water from a common source upon a particular tract of land . . . is clearly a property right of great value .... The decision of sucb a matter, after notice and a hearing is clcarly the exercise of a judicial function." Ibid. at 19, 120 Pac. at 782.

Note that this same type of procedural test has been applied by the supreme court in arriving at the conclusion that the Industrial Accident Commission exercises judicial power. Western Metal Supply Co. v. Pillsbury, sutpra note 5. 
So much for preliminary observations. Now for a brief glance at illustrative types of local board functions considered in relation to their reviewability.

(1) Licensing proceedings. The early cases involving issuance of ferry licenses have already been referred to. ${ }^{37}$ They definitely placed licensing proceedings of this type in the category of judicial functions, and, as such, reviewable on certiorari. As to other types of licenses issued by local boards or officers, there have not been a great many really clear-cut holdings. The more recent decisions have tended to emphasize the requirement of what is referred to as "discretionary judgment", to be exercised upon evidence to be heard by the board, as a factor in determining whether the licensing function is judicial or merely ministerial..$^{38} \mathrm{Or}$, as one opinion has stated it:

"When a board of supervisors is charged by law with the duty of issuing licenses upon specified terms and conditions, that tribunal becomes a quasi-judicial body for determining the facts and exercising sound and reasonable discretion in the performance of its duty." 39

Such statements seem to imply either that in all cases where the local licensing board's decision is to be based on determinations of fact, such board acts judicially, or that the "judicial" nature of its power depends upon the extent of leeway or "discretion" allowed the board in granting or denying the license upon the facts adduced before it.

(2) Assessment and tax proceedings. When the local board sits as a board of equalization to review individual assessments, to hear claims of taxpayers for reduction of assessed valuation, and to assess "escaped" property, it acts in a judicial capacity. ${ }^{40}$ If in any such proceeding a jurisdictional question is present, such, for example, as the failure to give notice to the taxpayer of intention to increase his assessment, the board's action may be challenged on certiorari. ${ }^{41}$ On

37 Supra notes 14,16 and 17.

38 Great Western Power Co. v. Board of Super's of Plumas County (1913) 21 Cal. App. 146, 131 Pac. 88; Rigdon v. Common Council of the City of San Diego (1916) 30 Cal. App. 107, 157 Pac. 513.

39 Martin v. Board of Super's of the County of Lake (1933) 135 Cal. App. 96, 100, 26 P. (2d) $843,845$.

40 People v. Goldtree (1872) 44 Cal. 323; City of Oakland v. Southern Pac. Co. (1900) 131 Cal. 226, 63 Pac. 371; Los Angeles etc. Co. v. County of Los Angeles (1912) 162 Cal. 164, 121 Pac. 384. See also Holbrook, Judicial Review of Determizations by County Boards of Equalization (1941) 14 So. CaLTF. L. REv. 276.

41 Huntley v. Board of Trustees (1913) 165 Cal. 298, 131 Pac. 859; Birch v. Board of Super's of the County of Orange (1923) 191 Cal. 235, 215 Pac. 903. 
the other hand, mere errors of judgment in determining the amount of assessed value are not jurisdictional and therefore are not open to attack on such review. ${ }^{43}$

(3) Street opening, street improvement, and special district proceedings. As the cases previously mentioned have indicated, a preliminary resolution of intention to order a particular street extended or improved is legislative in nature. ${ }^{43}$ The actual ordering of the extension or improvement, however, and the determining of individual property assessments in connection therewith, is held to be a judicial

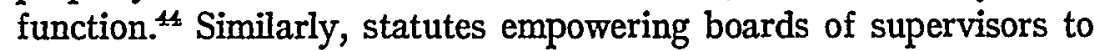
create special districts such as irrigation districts, ${ }^{45}$ sanitary districts, ${ }^{46}$ or fire protection districts, ${ }^{47}$ or to order changes in the boundaries of local school districts, ${ }^{48}$ to the extent that the action of the local board involves ascertamment of facts and the statute expressly or unpliedly provides for notice and hearing by the board, contemplate the performance of judicial functions. ${ }^{40}$ But where a statutory authorization to the local board concerning the annexation of mumicipal territory does not provide for notice and hearing of protests or the exercise of judgment in passing upon petitions calling the annexation election, the board's act in approving such petitions has been regarded as nimisterial and not subject to certiorari. ${ }^{50}$

(4) Appointment, compensation, and removal of officers. Apart from civil service matters noted later, there are questions of judicial function in comrection with the appointment of local officers. Thus,

42 Central Pac. R. R. v. Board of Equalization of Placer County (1872) 43 Cal. 365 ; Farmers' etc. Bank v. Board of Equalization of Los Angeles (1893) 97 Cal. 318, 32 Pac. 312.

43 Wulzen v. Board of Super's of the City and County of San Francisco, supra note 33; Quinchard v. Board of Trustees, supra note 34.

44 Wulzen v. Board of Super's of the City and County of San Francisco, supra note 33; Cutting v. Vaughn (1920) 182 Cal. 151, 187 Pac. 19. See also Keys v. Board of Super's of Marin County (1871) 42 Cal. 252; Barber v. Board of Super's of the City and County of San Francisco (1872) 42 Cal. 630; Kimball v. Board of Super's of Alameda County (1873) 46 Cal. 19.

45 Imperial Water Co. v. Board of Super's, supra note 35; Miller \& Lux v. Board of Super's (1922) 189 Cal. 254, 208 Pac. 304.

16 Stumpf v. Board of Super's of San Luis Obispo County (1901) 131 Cal. 364, 63 Pac. 663.

47 Norman v. Cogswell (1927) 82 Cal. App. 159, 255 Pac. 251.

48 Crane v. Board of Super's of the County of Los Angeles (1936) 17 Cal. App. (2d) 360, 62 P. (2d) 189.

49 Broyles v. Mahon (1925) 72 Cal. App. 484, 237 Pac. 763.

50 Wolfskill v. City Council of Los Angeles (1918) 178 Cal. 610, 174 Pac. 45. 
the earlier cases adopted the view that in creating a new office, ${ }^{51}$ or in fixing official salaries or compensation, ${ }^{62}$ or in canvassing election returns and declaring the result thereof, ${ }^{53}$ a local board might be acting judicially-a view which has been modified somewhat by later emphasis on the proper distinction between legislative and judicial functions. ${ }^{54}$ The judicial nature of local board action in passing upon official bonds, and in declaring an office vacant for insufficient bond, as has been noted, subjects such action to review on certiorari. ${ }^{55}$

In upholding the delegation by charter to a local board of the power to remove appointive officers, the court has considered such power to be judicial. ${ }^{56}$ It is, however, a power that must be expressly granted; where the charter is silent, an order of the board removing an officer is subject to annullinent on certiorari. ${ }^{57}$ The test for determining when the power is judicial has been given as follows:

"The removal of an officer involves the exercise of judicial functions only when the law by which the power is conferred requires notice and a hearing of the charge as a condition precedent to the removal." "ws

Decisions of the district courts of appeal also suggested a limitation on the strictly judicial character of the removal power by holding that, so far as concerns disqualification of members of the board to

51 Robinson v. Board of Super's of the City and County of Sacramento, supro note 27 .

62 People v. Supervisors of El Dorado County, supra note 21; El Dorado County v. EIstner, supra note 26; Robinson v. Board of Super's of the City and County of Sacramento, supra note 27 .

63 Whitney v. Board of Delegates of S. F. Fire Dept., supra note 25.

54 Smith v. Strother, supra note 32.

E5 Supra note 24.

56 Croly v. Board of Trustees of the City of Sacramento (1897) $119 \mathrm{Cal} .229,51$ Pac. 323. See also Boyd v. Pendegast (1922) 57 Cal. App. 504, 207 Pac. 713.

57 Legault v. Board of Trustees of the City of Roseville (1911) 161 Cal. 197, 118 Pac. 705.

68 Concurring opinion of Finlayson, P. J., in Sweetnam v. Board of Police Com'rs (1922) 56 Cal. App. 644, 649, 206 Pac. 102, 104. Counparable problems lave arisen in connection with the function of local boards in denying officers' pensions. Thus, where the local charter confers upon the board "no authority to lear and determine a question" or "to decide a question" in connection with an officer's eligibility to a pension, its action in denying the same is "ministerial only" and not "judicial". French v. Cook (1916) 173 Cal. 126, 160 Pac. 411; Sleehan v. Board of Police Com'rs (1925) $197 \mathrm{Cal}$. 70, $239 \mathrm{Pac}$. 844. Such statements are unfortunate, both in their literal ineaninglessness and in their result. Practically every action, whether "ministerial" or not, involves a decision. By broadening this class of so-called "ministerial" acts, these cases have made such determinations final and have practically precluded judicial review thereof. 
act, the function is not so judicial that strict rules of disqualification apply. ${ }^{59}$ Recent cases, referred to later herein, have reopened the question as to nature and review of the removal power.

(5) Civil service matters. Beginning with Cook v. Civil Service Commission $^{60}$ in 1911, the California Supreme Court has been confronted from time to time with the problem as to when a local board of civil service commissioners acts judicially, so as to subject its proceedings and determinations to review on certiorari. In that case the court held the conducting and grading of a promotional examination not to be a judicial function. "Having jurisdiction to act, and not acting judicially in holding examinations, the civil service commissioners, even if acting unfairly, could not have their action subjected to examination by a writ of review." 61 By a parity of reasoning, the court has consistently refused to interfere with determinations of such boards as to nature and scope of civil service tests, relative weights accorded to qualifications, and termination of eligible lists. ${ }^{02}$ On the other hand, a charter provision conferring upon civil service commissioners power to "hear and determine" charges in proceedings for removal of officers was held to vest the board with judicial functions, thereby making its order subject to review on certiorari. ${ }^{63}$

\section{THE SCOPE OF CERTIORARI}

Any discussion of certiorari in relation to locai boards and officers would be incomplete without at least a passing reference to the nature and scope of the review afforded by the writ in such cases. In other states, the common-law writ of certiorari, when used to review local

59 Grosjean v. Board of Education (1919) 40 Cal. App. 434, 181 Pac. 113; Butler v. Scholefield (1921) 54 Cal. App. 217, 201 Pac. 625.

60 (1911) 160 Cal. 589, 117 Pac. 663.

$61 \mathrm{Ibid}$. at 596, $117 \mathrm{Pac}$. at 666 . Regarding himitations on the use of mandamus in civil service examination matters, see Mitchell v. McKevitt (1932) 128 Cal. App. 458, 17 P. (2d) 789, (1934) 7 So. CaLIE. L. REv. 477.

62 Maxwell v. Civil Service Comm. (1915) 169 Cal. 336, 146 Pac. 869; Pratt v. Rosenthal (1919) 181 Cal. 158, 183 Pac. 542; Mann v. Tracy (1921) 185 Cal. 272, 196 Pac. 484.

63 Garvin v. Chambers (1924) 195 Cal. 212, 232 Pac. 696, (1925) 13 CaLtF. L. Rev. 341. See also Klevesahl v. Byington (1934) 1 Cal. App. (2d) 671, 37 P. (2d) 179, holding that where such determination requires exammation of evidence and decision of law and fact, it is not ministerial, and therefore mandamus will not he. Cf. Fonseca v. Goodwin (1935) 4 Cal. App. (2d) 58, 40 P. (2d) 570, holdimg that where the city charter does not provide for or contemplate a trial upon charges made, or require the order of discharge to be based upon such a trial, such order is not a judicial but a ministerial act, and certiorari will not lie. 
board determinations, has been held to fulfill a broader function than when applied to lower courts and judicial tribunals. In the latter situation it is restricted to the narrower, traditional office of reviewing only questions of excess of jurisdiction. In the case of local boards, however, where no other method of review or direct attack is available, the office of the common-law writ has been extended to cover all questions of regularity of the proceedings, including review of the record to determine whether, as a matter of law, there is any evidence to support the board's decision. ${ }^{64}$

In California, from an early date, the statutory provisions for certiorari have authorized its issuance only in cases where the tribunal or board has exceeded its jurisdiction, ${ }^{65}$ and have restricted its scope to determining "whether the inferior tribunal, board, or officer has regularly pursued the authority of such tribunal, board, or officer". Did this prescribe a narrower rule than that which obtained in other states under common-law principles? The supreme court apparently thought so at first, both as to the province of the writ and as to the types of tribunals to which it could apply. ${ }^{6 \pi}$ Even after the availability of certiorari to review local boards had become accepted, the review was still limited to questions of "power or jurisdiction", although on the question of jurisdiction it extended to every issue of law and fact involved therein. ${ }^{68}$ In Central Pacific $R$. $R$. v. Board of Equalization of Placer Count $y^{69}$ the court, after holding that the statutory expressions "has exceeded the jurisdiction of such tribunal, board or officer" and "has regularly pursued the authority of such tribunal, board or officer" presented "substantially the same idea", went on to state:

"Mere irregularity intervening in the exercise of an admitted jurisdiction-mere mistakes of law committed in conducting the proceedings in an inquiry which the Board had authority to entertain-as, for instance, the admission of evidence not the best in degree, or not applicable to the issue in hand, are not to be considered here upon certiorari, otherwise that writ is to be turned into a writ of error." 70

64 People v. Board of Police (1868) 39 N. Y. 506; People v. Assessors of Albany (1869) 40 N. Y. 154; Milwaukee Iron Co. v. Schubel (1872) 29 Wis. 444.

65 California Practice Act of 1851 \$ 456; Cal. Code Civ. Proc. \$ 1068.

66 California Practice Act of 1851 \$ 462; Cal. Code Civ. Proc. $\$ 1074$.

67 People v. Hester, supra note 18.

6s Whitney v. Board of Delegates of S. F. Fire Dept., supra note 25.

69 Supra note 42.

70 Ibid. at 367. 
On such review, also, the court is confined to a consideration of the record certified to it. There have been occasional assertions that evidence on jurisdictional facts outside of the record could be considered by the court, and that the evidence in the record in support of jurisdiction must accord strictly "with the rules of exidence recognized by the courts and the common law". ${ }^{71}$ These statements, however, were later disavowed in favor of more liberal rules of evidence for local administrative proceedings and determinations. ${ }^{72}$

In all of these cases, the court seems to have paid at least lip service to the view that certiorari lies only to review questions involving the jurisdiction of the local board. There are recent indications, however, that this concept of "jurisdiction" may be extended, as far as review of the evidence is concerned, to allow the courts to determine "whether there is any substantial evidence to support the findings of the board". ${ }^{73}$ If so, this will bring the California view into line with those decisions in other states which have similarly extended certiorari in the review of local boards. ${ }^{74}$

\section{RECENT DECISIONS AND CURRENT PROBLEMS}

Notwithstanding the express distinction in the Standard Oil and Drummey cases between local boards and state-wide administrative agencies, the inpact of those decisions was bound to cause a re-appraisal of the former doctrines concerning judicial review of local boards and agencies. For the most part, the district courts of appeal have accepted the dicta on the point, and have adhered to the rule that local boards contimue to be proper repositories of judicial power. There is sonie disagreement, however, as to the source of such power. Thus, in Ludolph v. Board of Police Commissioners ${ }^{75}$ an order of the

71 Stumpf v. Board of Super's of San Luis Obispo County, supra note 46.

72 Wolfskill v. City Council of Los Angeles, supra note 50, at 614, 174 Pac. at 47: "We are of opinion that the trend of both recent legislation and decision has been toward a relaxation of this rigid rule in respect to the procedure before official bodies chiefly political in their character and powers and only occasionally exercising judicial functions, with a view to upholding the action of such bodies which, though informal in some respect, is taken with a view to advancing the public interest and welfare of the community within the limited range of their jurisdiction."

73 Naughton v. Retirement Board of S. F. (Feb. 28, 1941) 43 A. C. A. 286, 2 Cal. Dec. 648,110 P. (2d) 714, concurring opinion of Peters, J., quoted infra note 81 . For a discussion of the traditional principles regarding "jurisdictional facts" in relation to judicial review of local administrative boards, see (1925) 13 CALIF. L. REv. 341.

74 Cases cited supra note 64.

75 (1938) 30 Cal. App. (2d) 211, 86 P.'(2d) 118. 
San Francisco Board of Police Commissioners, dismissing a police officer after hearing, was held to be a judicial determination sanctioned by the provisions of article XI, section $81 / 2$, concerning municipal charters. Removal proceedings by the City Commission of Fresno have been held to be so far judicial as to require disqualification of a member of the Commission who filed the charges on which the removal action was based. ${ }^{76}$ In a subsequent decision arising out of the same proceedings, the district court of appeal upheld the propriety of certiorari to review such local board determinations, and pointed to the distinction announced in the Standard Oil case. ${ }^{77}$ But its attempted rationalization of the distinction is seemingly at variance with the view both of the Ludolph case and of the early decisions as to the source of the judicial power which such boards exercise. Referring to article VI, section 1 , the court states:

"The same section of the Constitution gives to the legislature the power to establish inferior courts in any incorporated city or town, township, county or city and county.' Under this provision we have no difficulty in concluding that the legislature may, either by general law or through the provisions of a charter, vest judicial powers in boards or commissions having the limited territorial jurisliction named in the Constitution." 78

This might be taken to mean either that such boards and commissions are "inferior courts", or that a part of the judicial power in article VI is somehow transplanted by the legislature in establishing local governments under article. XI by general law or through charter provisions.

In the still more recent case of Dierssen v. Civil Service Commis$\operatorname{sion},{ }^{79}$ involving mandamus to compel petitioner's reinstatement on a local civil service eligible list, the view adopted as to the source of judicial functions exercised by local boards is more in accord with the Ludolph case as to the source of judicial power exercised by such boards. The court's interpretation of the statement in the Drummey case that local boards "are governed by special constitutional provisions" ${ }^{80}$ is that this obviously refers to article XI, sections 6 and

76 Nider v. Homan (1939) 32 Cal. App. (2d) 11, 89 P. (2d) 136. Cf. cases cited supra note 59 .

77 Nider v. City Commission (1939) 36 Cal. App. (2d) 14, 97 P. (2d) 293.

78 Ibid. at 28,97 P. (2d) at 300.

79 (Feb. 17, 1941) 43 A. C. A. 52, 2 Cal. Dec. 428,110 P. (2d) 513.

80 Supra note 8. 
$8 \mathrm{I} / 2$, authorizing the establishment of municipal corporations and their government by general laws or by charter, respectively.

Even more significant, however, are the observations in the Dierssen case on the extent of fact-finding finality that may be conferred upon local boards under the constitutional sections cited, and on the correlative strictures upon judicial review thereof:

"Under these provisions a chartered city or city and county may lawfully confer quasi judicial power on boards or commissions dealing strictly with municipal affairs, such as the power to determine facts, and, if such finding is inade, the courts may interfere only where the board acts arbitrarily, capriciously, or fraudulently. Stated another way, the courts are empowered to interfere with the findings of such boards only where a clear abuse of discretion is alleged and proved. If there is any substantial evidence to support the board's findings, the courts are powerless to interfere." 1

This recognition that a charter provision may confer upon a local board or officer the power to make determinations of fact which are binding upon the courts is in line with prior decisions requiring an absence of substantial evidence or a clear showing of abuse of discretion as a basis for judicial intervention. ${ }^{82}$

The 1941 session of the California Legislature has also been con-

81 Supra note 79, at 59, 2 Cal. Dec. at 432,110 P. (2d) at 517, concurring opinion of Peters, $J$. While the Dierssen case involved the writ of inandanus rather than certiorari, Justice Peters, in a concurring opinion in a later case, has pointed out that the two remedies are essentially the same, as far as the extent of the review of local board determinations is concerned. He states:

"...I believe that either mandamus or certiorari will lie to 'review' the determinations of local boards exercising judicial or quasi judicial powers. If certiorari is used, the extent of the review would be to inquire into the 'jurisdiction' of the local board. So far as the evidence is concerned, that would mean that the superior court's power is limited to determining whether there is any substantial evidence to support the findings of the board. If mandamus is used, the extent of the 'review' is to determine... whether 'the local board has acted arbitrarily and clearly in abuse of its discretion.' So far as the evidence is concerned, that means that the superior court's power is limited to determining whether there is any substantial evidence to support the findings of the board.... Whichever remedy is used, so far as the evidence is concerned, the extent of the 'review' is exactly the same. The only practical difference between the two remedies is that in certiorari the court may annul the order of the board, while in mandamis the court issues a peremptory writ. Wbichever remedy is used, the superior court should be limited to the record produced before the board." Naughton v. Retirement Board of S. F., supra note 73 , at 294,2 Cal. Dec. at 653,110 P. (2d) at 718.

82 Peters v. Sacramento City Employees' Retirement System (1938) 27 Cal. App. (2d) 10, 80 P. (2d) 179; Allen v. McKinley (Jan. 22, 1941) 42 A. C. A. 589, 1 Cal. Dec. 891,109 P. (2d) 429, Sup. Ct. hearing granted; Rhodehanel v. Civil Service Board (Jan. 22, 1941) 42 A. C. A. 601, 1 Cal. Dec. 897, 109 P. (2d) 436, Sup. Ct. hearing granted. 
cerned with the problems of administrative finality and judicial review of local boards. In a proposed constitutional amendment to empower the legislature to provide for judicial review of administrative officers, boards, commissions or agencies ${ }^{83}-$ a measure designed to overcome the effect of the Standard Oil case as to state-wide administrative agencies ${ }^{\mathrm{si}}$ _an effort has been made to give express constitutional sanction to the conferring of fact-finding finality upon local boards. In its latest amended form at the time of this writing, the proposal contains the following provision:

"When any city or city and county, which has adopted or shall adopt a charter in pursuance of this Constitution, has provided or shall provide by charter, by any amendment thereof, or by ordinance, that decisions of questions of fact made by any administrative officer, board, commission or agency in respect to municipal affairs shall be final, no court of this State shall have power to set aside such finding of fact if there is substantial evidence to support it." ${ }^{85}$

At first blush, the proposal seems to extend somewhat the doctrine above quoted from the Dierssen case, since it would permit the conferring of administrative finality "by ordinance" as well as by charter. When construed in conjunction with the purpose and context of the entire proposed constitutional amendment, however, the reason for such extension in the case of local boards becomes apparent. As to state-wide agencies, the state legislature is to be given power to provide by statute that findings of fact by such agencies, if supported by substantial evidence, shall not be set aside by the courts. As to local administrative boards and officers, the local legislative body should, with respect to municipal affairs, be placed in the same position; that is, it should be given, or permitted to receive, similar authority to provide by ordinance that findings of fact by local boards, if supported by substantial evidence, shall be final. ${ }^{86}$

83 (1941) Senate Constitutional Amendment No. 8.

84 See discussion by Professor McGovney, supra note 7, at 159.

85 (1941) Senate Constitutional Amendment No. 8, as amended in Assembly May 23, 1941, p. 1, 1. 17-p. 2, 1. 4.

${ }^{86}$ It should be noted that the sentence quoted from the amendment applies only to chartered cities and cities and counties and not to counties which have adopted or may adopt charters under article XI, section $7 \mathrm{r} / 2$. Whether this distinction was intentional or inadvertent, it is probably offset in part by the following sentence inserted in the proposal on May 23, 1941:

"Nothing in this section shall be construed as limiting the power of any county, city, or city and county under this Constitution to make and enforce within its limits local, police, sanitary and other regulations and, when not in conflict with general law, 
By further provisions of the same proposal, the legislative power to provide appropriate methods of judicial review, whether by certiorari or by other writ or procedure, would, as to both state-wide and local admimistrative agencies, and subject to the limitations above noted, become plenary. ${ }^{8 \tau}$ As to scope of the review to be granted, this would naturally depend upon the extent to which administrative fact-finding finality has been conferred by the appropriate legislative body. In the case of state-wide agencies, the legislature could, if it chose, provide for a complete review as to both law and facts. In the case of local boards and officers in chartered cities and cities and counties, the scope of review of determinations involving municipal affairs would depend upon whether or not the charter or a local ordinance specified that decisions as to facts should be final. If so, the courts would be bound by such findings of fact "if supported by substantial evidence".

Meanwhile, the several recent decisions of the district courts of appeal have re-examined for us the questions as to the proper scope and office both of certiorari and of mandamus in the review of local board determinations. ${ }^{88}$ It is possible that in the near future we may have a definitive clarification front the supreme court, in which these points will be further elaborated and crystallized. Notwithstanding the long history of certiorari and the local boards in California, there is still need for a clear analysis and understanding of the proper basis, inethods and scope of the review of local administrative determinations by the courts.

to provide by ordinance that decisions of questions of fact made by any administrative officer, board, commission or agency shall be final." Ibid. at p. 2, 11. 4-11.

87 Ibid. at p. 2, 11. 11-26.

88 Allen v. McKinley; Rhodehamel v. Civil Service Board, both supra note 82; Dierssen v. Civil Service Comm., supra note 79; Naughton v. Retirement Board of S.F., suspra note 73; Vincent Petroleum Corp. v. City of Culver City (March 18, 1941) 43 A. C. A. 591,3 Cal. Dec. 15, 111 P. (2d) 433.

In one recent decision by the supreme court mandamus was held to be unavailable to attack the order of a city board of zoning appeals denying a request for variance. The court's reasoning was in part as follows: "When the board of directors of Pasadena demed petitioners' application for a variance it did not take away a property right, but merely refused to grant a favor. Its action left the petitioners' property subject to the zoning restrictions then in force. If these provisions invade ... [their] constitutional rights there is an appropriate remedy open to them, but under the circumstances here shown mandamus will not be to review the decision denying a variance." Rubin $v$. Board of Directors (1940) 16 Cal. (2d) 119, 126, 104 P. (2d) 1041, 1044. The court did not specify what the appropriate remedy would be, nor how it should be invoked. Presumably, however, the validity of the zoning ordinance would be attacked by seeking an injunction to restrain its enforcemnt, as in Jones v. City of Los Angeles (1930) $211 \mathrm{Cal}$. 304, 295 Pac. 14, or by a suit for declaratory relief, as in Andrews v. City of Piedınont (1929) 100 Cal. App. 700, 281 Pac. 78. 